\title{
Perbedaan kadar hemoglobin pada mahasiswa Fakultas Kedokteran Universitas Sam Ratulangi berdasarkan kualitas tidur
}

\author{
${ }^{1}$ Lillian Sarjono \\ ${ }^{2}$ Karel Pandelaki \\ ${ }^{2}$ Jeffry Ongkowijaya
}

\author{
${ }^{1}$ Kandidat Skripsi Fakultas Kedokteran Universitas Sam Ratulangi Manado \\ ${ }^{2}$ Bagian Ilmu Penyakit Dalam Fakultas Kedokteran Universitas Sam Ratulangi Manado \\ Email: lillianfloresta101194@gmail.com
}

\begin{abstract}
Sleep is defined as a subconscious condition when the individual may be arose from sleep by giving him or her with stimulation which is a crucial process for human beings in the formation of new body cells, the improvement of damaged cells, and to maintain the balance of body metabolism and biochemistry. The quality of sleep described by less time of sleep have impact on the body, as biological process taking place at the moment of sleep would be disturbed. One of them is disturbance in the formation of hemoglobin in which a change shall be occurring where the content of hemoglobin is lower than its normal value. This study is analytical descriptive using a cross-sectional approach. Of 78 samples under study, the good quality sleep is 7 persons $(9.0 \%)$ and the bad is 71 persons $(91.0 \%)$. Normal content of hemoglobin is 40 person $(51.3 \%)$ and abnormal is 38 persons $(48,7 \%)$. The good quality sleep and normal content of hemoglobin is 4 persons $(57.1 \%)$ and abnormal is 3 persons $(42.9 \%)$. The bad quality sleep and normal content of hemoglobin is 36 persons (50.77\%) and abnormal is 35 persons (49.3\%). Conclusion: Most of students at Faculty of Medicine, Sam Ratulangi University, have bad quality sleep and normal content of hemoglobin. There are no differences between the content of hemoglobin from the 5th semester student in Medical Faculty student with who has good and bad sleep quality.
\end{abstract}

Keywords: quality of sleep, hemoglobin

Abstrak: Tidur didefinisikan sebagai suatu keadaan bawah sadar saat orang tersebut dapat dibangunkan dengan pemberian ransangan yang juga merupakan proses yang sangat dibutuhkan manusia untuk pembentukan sel-sel tubuh yang baru, perbaikan sel-sel tubuh yang rusak maupun untuk menjaga keseimbangan metabolisme dan biokimiawi tubuh. Kualitas tidur yang digambarkan dengan waktu tidur yang kurang akan membawa dampak bagi tubuh karena proses biologis yang terjadi saat tidur akan ikut terganggu. Salah satunya adalah pembentukan kadar hemoglobin yang terganggu dimana akan terjadi perubahan dimana kadar hemoglobin menjadi lebih rendah dari nilai normalnya. Penelitian ini bersifat deskriptif-analitik dengan pendekatan potong lintang. Dari 78 sampel pemelitian, kualitas tidur yang baik sebanyak 7 orang $(9,0 \%)$ dan yang buruk sebanyak 71 orang $(91,0 \%)$. Kadar hemoglobin normal sebanyak 40 orang $(51,3 \%)$ dan tidak normal sebanyak 38 orang $(48,7 \%)$. Kualitas tidur baik dengan kadar hemoglobin normal adalah 4 orang $(57,1 \%)$ dan kadar hemoglobin tidak normal adalah 3 orang $(42,9 \%)$. Kualitas tidur buruk dengan kadar hemoglobin normal adalah 36 orang $(50,7 \%)$ dan kadar hemoglobin tidak normal adalah 35 orang $(49,3 \%)$. Simpulan: Sebaigan besar mahasiswa Fakultas Kedokteran Unsrat mempunyai kualitas tidur yang buruk dan mempunyai kadar hemoglobin yang normal. Tidak terdapat perbedaan kadar hemoglobin pada mahasiswa semester 5 Fakultas Kedokteran Unsrat dengan kualitas tidur yang baik dan yang buruk.

Kata kunci: kualitas tidur, hemoglobin 
Tidur didefinisikan sebagai suatu keadaan bawah sadar saat orang tersebut dapat dibangunkan dengan pemberian ransangan sensorik atau dengan rangsanan lainnya. ${ }^{1}$ Tidur merupakan proses yang sangat dibutuhkan oleh manusia untuk pembentukan sel-sel tubuh yang baru, perbaikan sel-sel tubuh yang rusak, memberi waktu organ tubuh untuk beristirahat maupun untuk menjaga keseimbangan metabolisme dan biokimiawi tubuh. $^{2}$

Kebutuhan waktu tidur bagi setiap orang berbeda-beda. Kebutuhan tidur pada orang dewasa berkisar 6-9 jam, dan pada usia lanjut berkisar 5-8 jam. Kebutuhan waktu tidur ini harus tercukupi agar kondisi fisik tubuh tetap terjaga. ${ }^{3}$ Prevalensi kurang tidur telah meningkat secara signifikan dalam setengah abad. Pada penelitian yang dilakukan di Jepang didapatkan 29\% responden tidur $<6$ jam, $21 \%$ memiliki prevalensi insomnia, dan $15 \%$ kondisi mengantuk yang parah pada siang harinya. ${ }^{2}$

Kualitas tidur yang digambarkan dengan waktu tidur yang kurang akan berdampak bagi tubuh karena proses biologis yang terjadi saat tidur akan ikut terganggu antara lain pembentukan kadar hemoglobin yang terganggu sehingga menjadi lebih rendah dari nilai normalnya. ${ }^{4,5}$

Hemoglobin adalah suatu protein majemuk yang tersusun atas protein sederhana (globin) dan radikal prostetik heme. Hemoglobin mengangkut oksigen dari kedua paru-paru ke jaringan tubuh dan mengangkut karbon dioksida dari jaringan tubuh ke kedua paru-paru. ${ }^{6}$ Menurut laporan Riskesdas 2013, prevalensi kadar $\mathrm{Hb}$ yang rendah berdasarkan usia didapati usia 15-24 tahun sebanyak 18,4\%, dan usia 25-34 tahun sebanyak 16,9\%. Berdasarkan jenis kelamin laki-laki sebanyak 18,4\%, dan perempuan sebanyak $23,9 \%{ }^{7}$

\section{METODE PENELITIAN}

Penelitian ini bersifat deskriptifanalitik dengan pendekatan cross sectional untuk mencari perbedaan kadar hemoglobin pada mahasiswa Fakutas
Kedokteran Universitas Sam Ratulangi Manado berdasarkan kualitas tidur.

Penelitian dilaksanakan selama bulan Oktober 2016 bertempat di Fakultas Kedokteran Universitas Sam Ratulangi. Populasi dalam penelitian ini merupakan mahasiswa angkatan 2014 (semester 5) FK Unsrat dengan jumlah 78 orang.

Kualitas tidur mahasiswa diukur dengan menggunakan kuesioner Indeks Kualitas Tidur Pittsburgh (PSQI) yang terdiri dari 8 pertanyaan. Kadar Hemoglobin diukur dengan menggunakan alat ukur Hemoglobin digital dengan kadar hemoglobin normal laki-laki : 13,5-16,5 $\mathrm{g} / \mathrm{dL}$ dan untuk perempuan : 12,1-15,1 g/dL.Data penelitian diolah dengan menggunakan uji statistik chi-square dengan derajat kepercayaan 95\%. Bila nilai $\mathrm{p}<0,05$ maka hasil perhitungan secara statistik menunjukkan adanya perbedaan yang bermakna antara kedua variabel.

\section{HASIL PENELITIAN \\ Karakteristik Sampel}

Secara umum didapatkan bahwa sampel dari penelitian berjumlah 78 orang yang berjenis kelamin laki-laki dan perempuan. Sampel yang berjenis kelamin laki-laki sebanyak 28 orang $(35,9 \%)$, dan yang berjenis kelamin perempuan 50 orang $(64,1 \%)$.

\section{Distribusi sampel berdasarkan kualitas tidur}

Dari 78 sampel penelitian berdasarkan kualitas tidur didapatkan sampel dengan kategori kualitas tidur yang baik sebanyak 7 orang $(9,0 \%)$ dan kualitas tidur yang buruk sebanyak 71 orang $(91,0 \%)$ dengan skoring rata-rata adalah 7,86 dengan nilai simpang baku 2,087. (Tabel 1)

Tabel 1. Distribusi sampel berdasarkan kualitas tidur

\begin{tabular}{lcc}
\hline Kualitas Tidur & $\mathrm{N}$ & $(\%)$ \\
\hline Baik & 7 & $9,0 \%$ \\
Buruk & 71 & $91,0 \%$ \\
\hline
\end{tabular}




\section{Distribusi Sampel Berdasarkan Kadar Hemoglobin}

Dari 78 sampel penelitian berdasarkan kadar hemoglobin didapatkan sampel dengan kategori kadar hemoglobin normal sebanyak 40 orang $(51,3 \%)$ dan kadar hemoglobin tidak normal didapatkan sebanyak 38 orang $(48,7 \%)$ dengan nilai rata-rata hemoglobin 13,281 dan nilai simpang baku 2,086 (Tabel 2).

Tabel 2. Distribusi Sampel berdasarkan Kadar Hemoglobin

\begin{tabular}{lcc}
\hline Kadar Hemoglobin & $\mathrm{N}$ & $(\%)$ \\
\hline Normal & 40 & $51,3 \%$ \\
Tidak Normal & 38 & $48,7 \%$ \\
\hline
\end{tabular}

\section{Distribusi Kadar Hemoglobin Berdasarkan Kualitas Tidur Baik}

Dari 78 sampel penelitian distribusi kadar hemoglobin berdasarkan kualitas tidur baik didapatkan sampel yang memiliki kadar hemoglobin normal dengan kualitas tidurnya baik sebanyak 4 orang $(57,1 \%)$ dan sampel yang memiliki kadar hemoglobin tidak normal dengan kualitas tidurnya baik sebanyak 3 orang $(42,9 \%)$ (Tabel 3)

Tabel 3. Distribusi Kadar Hemoglobin Berdasarkan Kualitas Tidur Baik

\begin{tabular}{ccc}
\hline Kualitas Tidur Baik & $\mathrm{N}$ & $(\%)$ \\
\hline Hb normal & 4 & $57,1 \%$ \\
Hb tidak normal & 3 & $42,9 \%$ \\
\hline
\end{tabular}

\section{Distribusi Kadar Hemoglobin Berdasarkan Kualitas Tidur Buruk}

Dari 78 sampel penelitian distribusi kadar hemoglobin berdasarkan kualitas tidur buruk didapatkan, sampel yang memiliki kadar hemoglobin normal dengan kualitas tidurnya buruk adalah sebanyak 36 orang $(50,7 \%)$ dan sampel yang memiliki kadar hemoglobin tidak normal dengan kualitas tidurnya buruk adalah sebanyak 35 orang $(49,3 \%)$ (Tabel 4.)
Tabel 4. Distribusi Kadar Hemoglobin Berdasarkan Kualitas Tidur Buruk

\begin{tabular}{llc}
\hline Kualitas Tidur Buruk & $\mathrm{N}$ & $(\%)$ \\
\hline Hb normal & 4 & $57,1 \%$ \\
Hb tidak normal & 3 & $42,9 \%$ \\
\hline
\end{tabular}

\section{BAHASAN}

Kualitas Tidur pada Mahasiswa Semester 5 Fakultas Kedokteran Unsrat

Berdasarkan hasil penelitian untuk kualitas tidur pada mahasiswa semester 5 Fakultas kedokteran Unsrat didapati nilai rata-ratanya adalah 7,86 . Hasil analisis ini membuktikan bahwa mayoritas mahasiswa semester 5 Fakultas Kedokteran Unsrat (71 orang) memiliki kualitas tidur yang buruk dan kualitas tidur yang baik hanya sebanyak (7 orang). Hal ini sejalan dengan hasil penelitian yang dilakukan oleh Cheng pada mahasiswa di Taiwan. Dari hasil penelitiannya didapati bahwa kualitas tidur yang buruk paling besar dialami oleh kelompok mahasiswa dengan prevalensi sebesar $19,71 \%$ sampai $57,6 \%{ }^{8}$

\section{Kadar Hemoglobin pada Mahasiswa} Semester 5 Fakultas Kedokteran Unsrat

Berdasarkan hasil penelitian untuk kadar hemoglobin pada semester 5 Fakultas kedokteran Unsrat didapati nilai rata-rata kadar hemoglobinya adalah 13,28. Hasil analisis ini membuktikan bahwa mayoritas mahasiswa semester 5 Fakultas Kedokteran Unsrat (40 orang) memiliki kadar hemoglobin normal dan kadar hemoglobin tidak normal didapatkan sebanyak (38 orang) saja.

Perbedaan Kadar Hemoglobin pada Mahasiswa Semester 5 Fakultas Kedokteran Unsrat Berdasarkan Kualitas Tidur

Setelah diuji menggunakan analisis bivariat dengan menggunakan Chi-Square, didapati nilai $\mathrm{p}>0,05$ yang menunjukkan bahwa tidak terdapat perbedaan bermakna antara kadar hemoglobin berdasarkan kualitas tidur. Penelitian ini tidak sejalan dengan penelitian yang dilakukan oleh Pai yang melaporkan bahwa kadar hemoglobin 
merupakan salah satu fakotr yang berhubungan dengan kualitas tidur. ${ }^{9}$

Hasil penelitian ini dapat dipengaruhi oleh karena sebagian mahasiswa tidak mengikuti penjelasan pengisian kuesioner dengan baik dan enggan bertanya kembali saat mengisi pertanyaan yang kurang dipahami sehingga cenderung mengisi kuesioner apa adanya. Hal ini dibuktikan dengan ditemukannya beberapa pertanyaan dalam kuesioner yang tidak dijawab atau di jawab tidak sesuai dengan apa yang peneliti maksudkan.

\section{SIMPULAN}

Dari hasil penelitian pada mahasiswa semester 5 Fakultas Kedokteran Universitas Sam Ratulangi dapat disimpulkan bahwa umumnya mahasiswa mempunyai kualitas tidur buruk dan kadar hemoglobin normal. Tidak terdapat perbedaan kadar hemoglobin pada mahasiswa dengan kualitas tidur yang baik dan yang buruk.

\section{SARAN}

1. Mahasiswa perlu memperhatikan kebutuhan tubuh akan tidur mengingat rata-rata kualitas tidur mahasiswa adalah buruk.

2. Penelitian selanjutnya menggunakan metode penelitian kohort prospektif dengan data primer agar peneliti dapat memperoleh keakuratan hasil.

3. Penelitian selanjutnya diharapkan mengambil periode penelitian yang lebih panjang agar banyak sampel yang boleh diperoleh.

4. Diharapkan agar dapat dilakukan lagi penelitian yang berkaitan dengan hubungan kualitas tidur dengan kadar hemoglobin agar didapatkan
DAFTAR PUSTAKA

1. Guyton AC, Hall JE. Aktivitas otak-tidur, gelombak otak, epilepsi, prikosis. Dalam : Rachamn LY, uartanto H, Novrianti A, Wulandari N, editors. Buku Ajar Fisiologi Kedokteran. 11 ${ }^{\text {th }}$ Ed. Jakarta : EGC.2008. h.777-86

2. Liu X, Uchiyama M, Kim K, Okawa M, Shibui K, Kudo Y, et al. Sleep Loos and Day Time Sleepiness in General Adult Population of Japan Pyschiatric research. 2000;93(1):1-11

3. Lumbantobing. Gangguan tidur. Jakarta: Balai Penerbit FKUI. 2008. h.59-61

4. Jhonson A, Dorshkid A. Stromal cell in myeloid and lymphoid longterm bone marrow cultures can support multiple hemopoietic lineages and modulate their production of hemopoietic growth factor. Dalam Kruger A, editor. The limits of normality in elderly patiens. Baillie're's Clinical hematology. 2009. Diakses dari: http://www.ncbi.nlm.nih.gov/pubmed /10699223 Diakses tanggal 28 juli 2016

5. Karjono BJ, Rahayu RA. Gangguan tidur pada lansia. Dalam : Boedhi DR, Martono $\mathrm{HH}$, editor. Buku ajar geriatri. $5^{\text {th }}$ Ed. Jakarta : Badan penerbit FKUI ; 2014. h.319-38

6. Sumardjo, Damin. Pengantar kimia. Jakarta: Buku Kedokteran EGC. 2006. h.1-27

7. Depkes RI. Riset kesehan dasar 2013. Jakarta.Diakses dari : www.depkes.go.id Diakses pada 20 juli 2016.

8. Cheng SH, Shih CC, Lee IH, How YW, Chen KC, Yang YK et al. A study on the sleep quality of incoming university students. Psychiatry Research 2012;193(3):270-4

9. Pai MF, Hsu SP, Yang SY, Ho TI, Lai CF, Peng YS. Sleep disturbance in chronic haemodialysis patients: The impact of depression adn anemia. Renal Failure. 2007;29(6):673-67. 